\title{
Erratum to: Molecular characterization of a rare, human-porcine reassortant rotavirus strain, G11P[6], from Ecuador
}

\author{
Krisztián Bányai • Mathew D. Esona • Tara K. Kerin · Jennifer J. Hull • \\ Slavica Mijatovic • Nancy Vásconez · Carlos Torres • Ana M. B. de Filippis • \\ Kimberly R. Foytich $\cdot$ Jon R. Gentsch
}

Published online: 15 December 2009

(C) Springer-Verlag 2009

\section{Erratum to: Arch Virol}

\section{DOI 10.1007/s00705-009-0499-1}

Unfortunately one of the co-author's name was mistakenly omitted.

The additional co-author name is Kimberly R. Foytich. The authors apologize for this oversight.

The correct author line should read: Krisztián Bányai, Mathew D. Esona, Tara K. Kerin, Jennifer J. Hull,
Slavica Mijatovic, Nancy Vásconez, Carlos Torres, Ana M. B. de Filippis, Kimberly R. Foytich, Jon R. Gentsch

Her affiliation is:

Kimberly R. Foytich

Gastroenteritis and Respiratory Viruses Laboratory Branch, Centers for Disease Control and Prevention, Atlanta, GA, USA

The online version of the original article can be found under doi:10.1007/s00705-009-0499-1.

K. Bányai

Association of Public Health Laboratories,

Silver Spring, MD, USA

e-mail: bkrota@hotmail.com

K. Bányai

Veterinary Medical Research Institute,

Hungarian Academy of Sciences, Budapest, Hungary

M. D. Esona - T. K. Kerin · J. J. Hull - S. Mijatovic .

K. R. Foytich · J. R. Gentsch ( $\square)$

Gastroenteritis and Respiratory Viruses Laboratory Branch,

Centers for Disease Control and Prevention,

Atlanta, GA, USA

e-mail: jrg4@cdc.gov

\section{N. Vásconez}

Coordinadora Nacional del PAI, Quito, Ecuador

C. Torres

Funcionario del Proceso de Ciencia y Tecnología,

MSP, Quito, Ecuador

A. M. B. de Filippis

Pan American Health Organization,

Immunization Unit, Washington, DC, USA 